Srđan M. Gajdoš

Original research paper

University of Novi Sad

UDC: $371.3: 7.07$

Faculty of Philosophy, Department of

DOI: $10.19090 / m v .2019 .10 .211-227$

Language

srdjangajdos@gmail.com

Olivera Lj. Korpaš

University of Szeged

Faculty of Arts and Social Sciences, English

Applied Linguistics

oliverakorpash@yahoo.com

\title{
POPULAR CULTURE IN THE CLASSROOM: THE ART OF HAVING FUN AND LEARNING
}

ABSTRACT: The aim of this paper is to examine a possible approach to teaching vocabulary by heavily relying on popular culture and test its efficiency in the mastery of vocabulary. It also attempts to determine how students perceive this approach as opposed to a more conventional one. The paper implies drawing conclusions based on the study conducted by the authors. The study analyses a sample of 30 elementary and secondary school students (B2 level) who attended English classes in a private language school in Novi Sad. The control group was taught vocabulary units by using the coursebook as suggested in the teacher's book. The experimental group used audio and visual material from songs, games and films. The mastery of vocabulary and the level of satisfaction with the class were higher in the experimental group.

Keywords: popular culture, vocabulary mastery, ESL, satisfaction.

\section{POPULARNA KULTURA U UČIONICI: UMETNOST ZABAVLJANJA I UČENJA}

APSTRAKT: Cilj ovog rada je da se pozabavi mogućim pristupom predavanju vokabulara oslanjanjem na popularnu kulturu i da se testira njegova efikasnost u savladavanju ovih jedinica. Rad takođe pokušava da ustanovi kako učenici doživljavaju ovaj pristup u odnosu na konvencionalni. Zaključci u radu doneti su na osnovu sprovedenog istraživanja. Istraživanje se bavi uzorkom od 30 osnovaca i srednjoškolaca (B2 nivo znanja) koji su pohađali kurs engleskog jezika u privatnoj školi u Novom Sadu. Jedinice vokabulara predavane su kontrolnoj grupi korišćenjem udžbenika na način koji je predložen u nastavnom planu za nastavnike. Eksperimentalna grupa koristila je audio- i vizuelni materijal iz pesama, kompjuterskih igrica i filmova. Učenici eksperimentalne grupe su bolje savladali jedinice vokabulara i pokazali su veći stepen zadovoljstva časom.

Ključne reči: popularna kultura, savladavanje vokabulara, engleski kao strani jezik, zadovoljstvo. 


\section{INTRODUCTION}

It is widely recognised that when children enter puberty, many of them are heavily immersed in some form of popular culture that originates in an Englishspeaking country. A logical step would be to bring such content into the classroom to some degree and exploit it linguistically. The reason why it should be introduced is to make the students more satisfied with what they are being taught. In turn, working in such conditions should lead to achieving better results in mastering the linguistic units.

In the empirical section of this paper, the aim will be to ascertain the effectiveness of the introduction of popular culture in the classroom. The students' satisfaction with the classes is expected to be higher in the experimental group as opposed to the control group. The next hypothesis has to do with mastering the vocabulary units that are being taught. The students of the experimental group are expected to do better than the control group. What distinguishes this research is a variety of forms of popular culture applied in one class as opposed to their separate application found in the body of case studies.

\section{LITERATURE REVIEW}

The aim of this part of the paper is to point out the advantages of using popular culture in the classroom as well as to examine the way it has been implemented more extensively in a number of case studies. In addition, the importance of learning satisfaction and its connection to popular culture is briefly discussed.

\subsection{The advantages of implementing popular culture in the classroom - a brief review of relevant case studies}

Kusnierek (2016: 33) conducted research on a sample of 28 students in a Polish elementary school. The students of the experimental group were asked to provide all the verbs that they knew within a short time limit and were then asked to name the songs in which the verbs appeared. They were played two songs and asked to identify all the verbs they recognised. They had to fill in the lyrics of a song with the provided verbs and sing it. Finally, they had to come up with their own sentences and use these verbs. Kusnierek (2016: 42) concludes that the experimental group performed better and that music is a good tool because songs imply the repetition of words. Students also want to discover their meanings and thus learn subconsciously. Israel (2013: 1360) conducted her research on a sample 
of South African secondary school students who first analysed three songs in class by listening to them and reading the lyrics. After enjoying the auditory aspect of the songs, they were told that the songs were actually poems set in motion, since analysing poems was generally perceived to be boring. Israel (2013) claims to have changed their perception of poems and they started enjoying them more.

As for utilising films in the classroom, Ismaili (2013: 125) discusses her experiment with university students, where she used ten-minute movie clips with the experimental group to facilitate the mastery of vocabulary, writing and speaking. After playing short clips, she asked them questions about the content in order to check their comprehension and told them to write a short essay and provide brief oral answers to her questions. The students of the experimental group predominantly expressed their satisfaction with the approach and scored better than the control group, which did not use movie clips. Kabooha (2016: 250-251) conducted her research on a sample of fifty Saudi university students, in which they were asked to guess the topic of the movies they were about to watch and they were given expressions that might be difficult to comprehend. After watching the chosen scenes, they were asked to answer a number of questions. They were told to keep vocabulary journals, write essays and do role-play, which most of them found useful and entertaining. Shing and Yin (2014: 50-52) conducted their research in a Malaysian secondary school in response to the students' poor verbalising abilities. After watching whole movies, the students watched 10-20 minute scenes and were expected to perform role-plays on identical or similar content. The results showed that their intonation, stress and pauses improved.

When it comes to applying computer games, Quijano-Cruz (2007: 151153) makes reference to RPG games and considers them a valuable tool because of the extent to which the users (learners) are exposed to the in-game dialogues. This author suggests using the transcripts of games in the classroom for analysis since it is a fun experience that the students can relate to. Each game has a certain cultural setting that the students can benefit from. Once they start playing this game at home, they can keep record of their progress in a journal. They could later be asked to write essays about it. Sylven and Sundqvist (2012: 302) conducted research on a sample of 86 Swedish teenagers who were told to play multi-player online roleplaying games at home, keep journals and record the number of hours they spent playing. After testing these students the researchers concluded that those who had been exposed to the games longer scored better on the test, especially with respect to vocabulary. Lam (2013: 90) conducted research on a sample of 91 freshmen students in Macau to see whether the use of two online games could help the students improve their vocabulary mastery. They played Fling the Teacher and 
Jeopardy in a computer classroom in order to learn new vocabulary. They completed a survey on how they felt about these classes and expressed their satisfaction. Lam concludes that such games can be vital in making the students more focused and persistent in language learning. Hansen (2018) provides very interesting hypothetical ways of implementing computer games into the classroom. He (2018: 55-56) explains that World of Warcraft can be played in a groups of three students who collaborate using Discord software, while trying to complete the levels. After doing the activity for 120 minutes, the students can present to the class how many levels they accomplished, what kind of characters they chose and what kind of difficulties they encountered.

\subsection{Learning satisfaction}

According to $\mathrm{Wu}$ et al. (2015: 2851-2852), learning satisfaction is the effect that the teaching and learning process has on the learners. These authors point out the importance that the teaching methods, course content and learning environment (among other factors) have on overall student satisfaction and their intention to continue learning. He goes on to say that this future intention of students depends on their previous or current learning experience. He concludes that the content is the most significant factor that determines their satisfaction and their willingness to continue. Renkema (2006) suggests that those courses that are positively evaluated are more likely to be continued in the future. Cheung (2001: 60) posits that teachers should take into account students' lives and interests when choosing the teaching material. In other words, creating a pleasant learning environment enables the students to thrive.

\section{RESEARCH METHODOLOGY}

This section of the paper deals with the empirical data gathered in the study, which will later be analysed.

\subsection{Participants}

The participants of this research were elementary and high school students who were attending a B2 course of English in a private language school in 2018 (Novi Sad, Serbia). There were 30 students ranging from the ages of 14 to 20. Prior to starting the course, they had been tested to ascertain which level they were. In other words, the groups in the school were formed based on their performance on the Oxford Placement Test. They had regular classes of English twice a week, an 
hour and a half per class. They were taught by two different teachers but the same material was used and they were taught at the same pace. The coursebook, workbook and audio material were from the New Opportunities UpperIntermediate (Harris, Mower \& Sikorzynska 2006) course. Of the total number of participants, 14 of them were female, while the remaining 16 were male. Although the students were members of four separate groups (classes) in the private school, they were merged into two groups for the purposes of the research.

\subsection{Research design}

Regarding the nature of this experiment, it is quasi-experimental since the choice of the participants was not completely random and they were members of already existing groups. Of the total number of four groups that had already been formed, two of them were taught using the material that they used regularly in the classes and were taught the traditional way. They were not merged physically into one group because of the limitation of space. However, special attention was paid to teaching these two physically separated classes of the control group and two classes of the experimental group in a uniform manner so as to keep the obtained data valid. Seven students from one group and eight from the other group could not be seated in one classroom, so they were taught in separate classrooms, on different occasions, by using the exact same material and methodology. The students in the control group were taught the lesson the way in which the coursebook naturally led them through the units, with the teacher closely following the instructions from the teacher's book. For the purposes of the research, the vocabulary was covered within the Warm-up unit of Module 10. The experimental group did the same vocabulary units, focusing on different material prepared by the instructor (author) and presented to them in a different format, which is further elaborated in subsection 3.4. They got a piece of paper with the exercises similarly phrased to the ones provided in the book, which the control group was using. The class lasted 90 minutes, although only the first 30 minutes (an extended and particularly long warm-up/lead-in stage) were taken into consideration and tested. The test lasted 15 minutes. The following 45 minutes, all the students were taught identically by moving onto the text from the book. This part of the class will not be discussed.

\subsection{Instrument (testing)}

The students of both groups were given the same anonymous immediate test after the end of the class in which they were asked to mark their gender. It 
consisted of four tasks. The first one (consisting of three questions) tested their knowledge of the dominant emotions and types of conflict that they discussed in the first task in class. The second task tested their knowledge of the expressions that were mentioned in class. In this exercise, the students were given multiplechoice answers. There were four options, only one of which was correct. There were twelve sentences with a gap that had to be filled. The third task tested their ability to remember the motives behind the conflicts that were discussed in class. They were not given any options here, but had to remember the motives and the brief situations (stories) from class that they were, at this point, expected to describe in a few sentences. There were seven motives and five stories to recall. No grammatical accuracy was required when grading this task, only factual precision. The fourth one had to do with the overall impressions of the students regarding their satisfaction with the course material from the warm-up stage. The questionnaire assessed their satisfaction with the class in terms of how much they liked the topic and the form it was presented in. This mini survey was provided in the form of a scale in which the students chose a number based on how much they agreed with the statements about the class they had. There were five such questions. The results were recorded in Excel, calculated and statistically presented in this paper.

\subsection{Data collection procedure}

As far as the presented content is concerned, the focus was on teaching vocabulary. In order to establish the differences between the conventional and prescribed method of presenting the vocabulary units on the one hand,and the alternative method on the other, the class was organised in the following way. The choice of units was narrowed down only to the topic of conflict. Since the coursebook always has an introductory warm-up section that teaches key vocabulary and gets the students engaged in the topic through related conversation, the task of the experimental group was no different. In the control group, the students were, as instructed in the teacher's book, asked to look at the photos (film scenes from Othello, Romeo and Juliet and Richard III) and guess who the people in the pictures were and what kind of situations they were in. They were also played three recordings that had to do with the plays and were told to match the recordings with the corresponding works by Shakespeare. In the experimental group, the pictures from the coursebook were replaced with different ones. The picture of Othello was replaced with a scene from Pretty Little Liars as an example of conflict resulting from jealousy. This film is obviously very popular among 
teenage and adolescent girls. A recognisable scene from this series was also played for them in the form of a two-minute YouTube video on a computer in the classroom. The picture from the film scenes of Romeo and Juliet, which can be found in their book, was replaced with a film scene from Star Wars, in which Luke Skywalker stands next to Darth Vader. The popular video showing the battle between the two was played for them as well. The third picture from the regular coursebook, which features a scene from the film adaptation Richard III, was replaced with a scene from the two popular computer games that primarily boys indulge in $\square$ Battlefield 5 and Call of Duty: Black Ops 4. The students were played a scene from both games, in which the different flags of the participating countries were clearly visible.

In the second task of the control group the students were asked to listen to the same recordings from the first task. These recordings were actually short excerpts of invented dialogues that had to do with the topic of three types of conflicts. This time, additional keywords were provided for them in a box. In this task, they had to insert the words into gaps next to other words in order to form expressions. The keywords were the following: argument, battle, clash, feud, fight, friction, gang, quarrel, a row, violence, war and warfare. The words they were expected to pair them with were: civil, decisive, heavy, street, rival, long-standing, family, gang, family, domestic, have and petty. The correct combinations appeared in the recordings. In the experimental group the students were played YouTube clips that contained these expressions, or, in most cases, simply implied these concepts without any concrete mention of the words. The teacher made it clear which combination they were listening to after hearing their guesses about the correct answer. This was done because it was not always possible to find a recording where the characters actually verbalised the exact combinations. For instance, decisive battle and heavy clash could be heard in the dialogues or read in the mission objectives in Battlefield 5 and Call of Duty: Black Ops 4. The expression civil war was placed within the context of the popular film Captain America: Civil War. Similarly to the previous two games, a clip from the film was played. Since all three sources have to do with historical events, some basic background was provided on the topic of Word War II and the American Civil War. Since English is spoken in a number of countries, its role in these events was also discussed briefly in an interactive manner. The students were first asked questions concerning what they knew about these historical events, with a quick recap on the teacher's part. The expression street fight was illustrated by playing The Dark Kight Rises, in which Batman and Bane fight in a chaotic conflict. The students were then provided with some basic information about the protagonist and 
the films that featured him. The expressions rival gang and gang warfare were illustrated with a short gameplay clip of GTA 4, in which this social phenomenon is heavily exploited. A scene from the film Godfather was used to explain longstanding friction, with a brief historical reference to the reality of the USA in the 1920s. The expression family feud was explained through the use of the iconic scene from Star Wars, in which Luke Skywalker is told by Darth Wader that he is his father. Domestic violence was put into perspective by showing a short clip from the film Twilight, in which the protagonist was often verbally abused by a young man. Family quarrel, have a row and petty argument were all taken from different scenes from Spider-man: Homecoming.

In the third task of the control group, a new box of keywords (ambition, fear, greed, hatred, intolerance, jealousy and revenge) was provided to the students. These words were the motives for committing certain crimes, which were listed on the right side of the page. The students were expected to match the motives to the five crimes and discuss this amongst themselves. Afterwards, they were asked to explain why such motives were behind the crimes and to give supporting evidence. This was done in the form of a story. The listed crimes were as follows: Woman mugged for 5 dollars; TV breeds copycat violence claims minister; Rebel leader replaces President; Boyfriend admits he was out of control and Police investigate increased attacks on immigrants. In the experimental group, the students were provided with the same keywords (motives) but the crimes were set within different contexts. For example, Eminem's line from Lose Yourself was provided as one of the possible instances of fear (His palms are sweaty, knees weak, arms are heavy). Another reference was made to a very popular singer Taylor Swift. One line from her hit You Belong with Me (And she'll never know your story like me) was given to the students of the experimental group. Ariana Grande's popularity was also taken into account, so a line from her song The Light Is Coming had to be included (The light is coming to give back everything the darkness stole). Reference was also made to the popular teenage novel The Hunger Games by Suzanne Collins. The line that was taken from this book was I'm more than just a piece in their Games. The list of quotes probably would not have been complete without including The Vampire Diaries (I don't trust easily, so when I tell you I trust you, don't make me regret it). The students were asked to explain what kind of motives or feelings could be traced to these statements. They were asked about the origin of these lines, without having to invent any story, but simply speculate about the reasons why such emotions were expressed. Close attention was paid to the overall popularity of the authors and their works to ensure that the students were as familiar with them as possible. 


\section{RESULTS AND ANALYSIS}

The results and the analysis of these findings will be discussed in the following sections. The obtained data will be observed in light of the questions themselves, comparing the control and experimental group.

\subsection{Control group (vocabulary mastery)}

In the control group the rate of success for the first task was not satisfactory, with $49 \%$ of correct answers. The first question in the first task (Table 1) was the following: What is the dominant topic in Shakespeare's Othello? Out of 15 students, four of them answered correctly, making it $27 \%$. Presumably, this was a play unfamiliar to the majority of the students and they were not able to recall it. This drama, despite being a good representation of jealousy, might not have been relatable content. Regarding the question What is the dominant topic in Shakespeare's Romeo and Juliet?, 13 (87\%) of them answered correctly, suggesting that this is something that was very recognisable since this content is ever-present in the world around us. The third question (What is the dominant topic in Shakespeare's Richard III?) was challenging for the majority of them since it might have been too monotonous to follow because of the number of historical figures present in the recording, and only five (33\%) of them were able to remember it. Although Shakespeare lies at the foundation of English culture, the students were not too familiar with him since they did not remember more than just the basics. The authors, however, do not suggest that Shakespeare's works deserve no mention in class. One way of teaching them might be by using modernised versions that are more appealing to teenagers.

Regarding the second part of the test, some of the questions they got are listed below. In addition to the questions, brief comments on the reasons why the students generally did them well or not have been provided.

1. If we don't act, the country will be split by war. (street, gang, civil, domestic)

2. The fate of the war lay in Stalingrad, where the battle of that front was waged. (petty, rival, long-standing, domestic)

3. There was a heavy in the streets of the city. (clash, feud, fight, friction)

4. After swearing at each other, it became physical and they started a street (battle, row, friction, fight) 
5. Since they also started selling drugs, they were considered a gang. (rival, violence, argument, row)

In total, the students did this section of the test at a satisfactory level. The overall percentage of the correct answers was $68 \%$. This relatively high score could most likely be attributed to the fact that they were played the exact same recording twice and that they could easily trace the sentences back to the original that they had heard them in. However, one should also note that there were three answers to be found in the first recording, five of them in the second one and three in the final one. The students had only three situations to match the words with. Although three situations are easy to remember, there were too many expressions to be matched with a small number of contexts. This could have resulted in some of the expressions being not that easily identifiable. Another reason for just a relatively good performance within this section of the test was the fact that the situations were quite monotonous in terms of how they were presented. The task in the book that covered these units was not particularly inspiring or creative since it merely listed the units they were supposed to match based on the listening. Consequently, this led to a lower rate in accuracy since the brain was not fully engaged in the activity itself. Not all twelve questions will be discussed in this analysis. It is worth noting that questions 1,2 and 10 were done significantly better than the other ones, probably due to the students' familiarity with the words argument, battle and violence. Questions 3, 4 and 6 were done worse than the others presumably because of the words clash, feud and friction, which proved to be difficult to understand.

The third section of the test dealt with the third task from class. The students were asked the following question: Name the seven motives (emotions) that were covered in class today and try to remember the five stories they were linked with today's discussion. Since the number of the units to be remembered was neither particularly long nor short, the relative success of the exercise and results should not surprise us. The overall score was $66 \%$ (Table 4), with most of the students struggling to remember the stories, which is quite surprising since there were only five of them. An explanation for this could be sought in the fact that these stories were heard in class for the first time, so they were not easy to identify. Since this task was done in groups, the students presumably remembered the ones that they took part in to elaborate and explain. The seven emotions themselves (marked in the test by numbers as they appeared in subsection 3.4.) were unexpectedly difficult and not many of them were remembered. The most difficult was 4. Intolerance, while the hardest stories were 9. TV breeds copycat 
violence claims minister. and 10. Rebel leader replaces President. The easiest were 6. Jealousy, 7. Revenge and 11. Boyfriend admits he was out of control. These instances may have been easier because the students could relate to them more.

\subsection{Control group (student satisfaction)}

The fourth section of the test was an equally interesting one, not in terms of accuracy but with regard to the way the students perceived the nature and success of the class, as well as how much they enjoyed it. These were the statements that they were provided with in the fourth section:

1. The class was successful.

2. The class was interesting.

3. I was motivated more than usually.

4. I was already very familiar with the content of today's class.

5. I would like to have a similar type of class next time.

The examinees were told to mark their answers on a scale from 1 to 5, with 1 being the weakest and 5 being the strongest degree of agreement with the statements. In the first question, there were eight (53\%) students who chose number 4, six (40\%) students that answered 5 and one (7\%) student that answered 3 (Table 4). This is a very high rate of success. This suggests that a more expected format of class was perceived to be useful in learning a language. For the next question, six (40\%) students answered with number 4 , five (33\%) with number 5 and four (27\%) with number 3 . This score indicates that their interest in the class was not particularly low and that popular culture presented in a more old-fashioned way (recordings and texts) can be perceived as appealing. When discussing the third question, nine of them $(60 \%)$ wrote 3 , which is significantly lower than the previous figures. Four (27\%) wrote 4 and two (13\%) of them wrote 2 . The first two statements had more to do with the role of the teachers, so most of them may have tried to stay positive and give good feedback. The third statement had more to do with them and the role of the material, so they may have been more sincere in this section. This is important to note because they might be hinting on whether the content had an impact on them, which it did not significantly. In the fourth one, the numbers were drastically lower than the other parts, with eight $(53 \%)$ of them writing 2, five (33\%) of them responding with 5, one (7\%) answering 4 and the same number of them answering 3. The figures suggest that the students could identify very few instances of popular culture from their own experience. With 
regard to the last question, they were again more positive, with seven (47\%) students answering 3, four (27\%) of them answering 4, two (13\%) of them answering 5 and the same number answering 2 . The figures indicate that the nature of the class sparked no special interest in the students and it was not a particularly memorable one.

\subsection{Experimental group (vocabulary mastery)}

The overall score in the experimental group for section one was $82 \%$. Since the focus of the experimental group was not merely on changing the form in which the material would be taught but also on improving and updating the content, the choice of the teaching resources was changed in the first task. The students were required to provide the dominant topic in the scene with Pretty Little Liars. Although this is not the dominant emotion of the whole series, the scene that they were played was very indicative of jealousy existing between the two groups of girls. Eleven (73\%) of them wrote the correct answer, which either implies that they were already familiar with this fact or that the context was presented in a format that they could easily commit to memory. This score is higher than that of the control group. The second question enquired about the type of conflict that, among other types, existed in the Star Wars. Twelve (80\%) answered correctly, presumably due to the universal popularity that could be attributed to that particular iconic scene. This is the only question that the control group did better, possibly owing to the fact that not all the students were too familiar with this film. When it comes to the third question, the students were enquired about the dominant type of conflict in Battlefield 5 and Call of Duty: Black Ops 4. Because of their popularity, it should not surprise us that 14 (93\%) of the participants answered correctly. Although the chosen computer games are tailored more to the male target group, it could be speculated that they were popular enough even for the females to be familiar with them. An alternative explanation might be that the games themselves are good representatives of the subject-matter they deal with and they were easily understood and remembered in class. This question was done significantly better than in the control group, possibly due to a better choice of content.

When it comes to the second section of the test, the results were higher than in the control group. The students scored an overall of $80 \%$, which is extremely satisfactory. An extremely high number of these contexts did not pose a real problem, probably due to the fact that most of the students had already been familiar with them. Not all of them were completely familiar with the content of all the 12 instances. Most of them were at least somewhat familiar with the films and 
games that served as the context in this particular part of the test, which will later be discussed when dealing with the fourth section of the test. It could be speculated that this rich diversity of contexts proved to be beneficial in the memorisation of the units since the brain identified them as different instances that are hard to confuse. The students were building upon content that they had already completely or at least vaguely been familiar with. This leads us to the conclusion that every effort should be made to combine familiar content with that which is not. A familiar setting should naturally be able to make up for the unknown content, which it links to itself and makes easier to comprehend and internalise. Interestingly, questions 2, 5 and 11 were done best, which again implies that the easiest words (battle, fight and war) were done better than the rest, which was a similar trend in the control group. Questions 4, 8 and 9 (feud, quarrel and row) were done poorly, which, similarly to the control group, suggests that difficult words were perceived as problematic regardless of the approach.

The third section was done extremely well, with an overall score of $87 \%$. By contrasting this figure with the corresponding one obtained in the control group, it could be speculated that the diversity of the material and easy identifiability of its nature has led to the students remembering most of the situations correctly. There was a correlation between remembering the words better when the situations were easy to remember. Since no story was invented in class in this exercise, the material was somewhat more familiar to them since they knew the story behind Eminem's rap duel or the story behind The Hunger Games. The male participants thrived mostly with the question related to Eminem, but so did the females. Most of the female participants (88\%) were able to recall the songs of Ariana Grande or Taylor Swift, as well as the plot of The Vampire Diaries. Most mistakes stemmed from the book The Hunger Games. This was possibly the result of the students not being avid readers. The results illustrate the fact that all the students did the question regarding Eminem with no mistakes. Surprisingly enough, almost the same can be said about the question regarding Ariana Grande and the Vampire Diaries, which suggests that both boys and girls are familiar with popular culture, even when it was not primarily intended for them.

\subsection{Experimental group (student satisfaction)}

The fourth section showed the greatest discrepancy between the two groups. The range of answers that could be found in their tests was extremely high. Twelve (80\%) of them expressed their complete satisfaction with the success of the class. Three (20\%) of them marked number 4 . When asked about whether the class 
was interesting, $14(93 \%)$ of them answered with 5, while one (7\%) learner answered with 4 . This piece of information is extremely valuable and encouraging since it gives the green light for including this type of content and methodology in the classroom a lot more extensively. In a very similar fashion, there were 14 $(93 \%)$ students who showed their agreement with the statement that they were extremely motivated in that class, with only one (7\%) student opting for number 4. Seven $(47 \%)$ of them stated that they were completely familiar with the topic they were taught, four $(27 \%)$ of them said they were very familiar and answered number 4. Two (13\%) of them opted for number 3 as well as number 2. For the last statement, thirteen $(87 \%)$ of them were completely in favour of having a similar lead-in class again, while one $(7 \%)$ learner answered with number 4 , which was the case for number 3 as well. The summary of all the scores and answers can be seen in Table 1.

Table 1. The scores expressed in percentage obtained in the 3 tasks and the questionnaire in both groups, along with the extent of agreement with the statements from task 4

The statements in question 4 with answers 4 and 5

\begin{tabular}{cccccccccc}
\hline Groups & Task & Task & Task & Overall & Statement & Statement & Statement & Statement & Statement \\
& 1 & 2 & 3 & & 1 & 2 & 3 & 4 & 5 \\
\hline Exper. & 82 & 80 & 87 & $\mathbf{8 3}$ & 100 & 100 & 100 & 75 & 95 \\
\hline Control & 49 & 68 & 66 & $\mathbf{6 1}$ & 93 & 73 & 27 & 40 & 40 \\
\hline
\end{tabular}

\subsection{Study limitations}

One of the shortcomings of this research is surely the small sample of students, making the results less reliable and relevant. Another drawback has to do with the very structure of the students, who ranged from those who were about to finish elementary school to those who had just started university. Obviously, such diversity in age implies different life experience, knowledge and interests although they were officially all at the same level. In addition, the difference in gender also greatly determines what they like and are familiar with. Moreover, the research was conducted within only one part of the class, which implies that other content could have interfered in the learning process. Another point is that the courses were taught by two different teachers. However, this did not influence the data since the experiment was conducted by the same one. 


\section{CONCLUSION}

The two hypotheses have been confirmed: the use of popular culture can play a role in boosting the students' satisfaction with class. This appears to be in correlation with better results and greater enjoyment. The implications of the experiment are certainly not that books are redundant. Although the method of teaching the students in the experimental group was unorthodox to say the least, the reason why the class and content were devised in such a manner was to showcase the genuine potential of applying popular culture in the classroom. The base texts that are found in the coursebooks can be used as the foundation of the class. What could possibly be done is simply to enrich the existing content with forms of popular culture that the teacher can provide. The inclusion of popular material that the learners are familiar with seems to play a role in student satisfaction. They appear to show greater enthusiasm when new units are presented to them by means of visual and audio material, such as games, films and songs.

\section{REFERENCES}

Cheung, C. (2001). "The use of popular culture as a stimulus to motivate secondary students' English learning in Hong Kong”. ELT Journal 55: 55-61.

Hansen, J. B. (2018). Computer Games and ESL Learning. Adger: University of Adger.

Harris, D, Mower, D \& Sikorzynska, A. (2006). New Opportunities UpperIntermediate Students' Book. Harlow: Pearson Education Limited.

Ismaili, M. (2013). The effectiveness of using movies in the EFL classroom - A study conducted at South East European University. MCSER-CEMAS (2): 121-132.

Israel, H. F. (2013). "Language learning enhanced by music and song". Literacy Information and Computer Education Journal (LICEJ) 2: 1360-1366.

Kabooha, R. H. (2016). "Using movies in EFL classrooms: A study conducted at the English

Language Institute (ELI), King Abdul-Aziz University". English Language Teaching 9: 248-257.

Kusnierek, A. (2016). "The role of music and songs in teaching English vocabulary to students". World Scientific News 43: 1-55.

Lam, S. L. (2013). "Use of gamification in vocabulary learning: A case study in Macau". Centre for English Language Communication (CELC) Symposium, Singapore. 
Quijano-Cruz, J. (2007). "Video Games and the ESL Classroom". The Internet TESL Journal 13: 151-184.

Renkema, A. (2006). "Individual learning accounts: A strategy for lifelong learning?". Journal of Workplace Learning 18: 384-394.

Shing, S. R. \& Yin, L. K. (2014). "Using films to teach speaking in the ESL classroom: A case study". UNISEL Journal of Social Sciences and Humanities 1: 50-56.

Sylven, L. K. \& Sundqvist, P. (2012). "Gaming as extramural English L2 learning and L2 proficiency among young learners". ReCALL 24: 302-321.

$\mathrm{Wu}, \mathrm{Y}, \mathrm{Hsieh}, \mathrm{L} . \& \mathrm{Lu}, \mathrm{J}$. (2015). What's the relationship between learning satisfaction and continuing learning intention? Procedia - Social and Behavioral Sciences 191: 2849-2854.

Srđan Gajdoš

Univerzitet u Novom Sadu

Filozofski fakultet

Olivera Korpaš

Univerzitet u Segedinu

Fakultet umetnosti i društvenih nauka

POPULARNA KULTURA U UČIONICI: UMETNOST ZABAVLJANJA I UČENJA Rezime

Rad se bavi korišćenjem proizvoda popularne kulture (pesama, filmova i kompjuterskih igrica) u predavanju stranog jezika. Analiza jezika lišena kulturološkog konteksta čini proces učenja odbojnim. Gradivo koje se predaje i uči često ume da bude suvoparno, i kao takvo, teže se usvaja. Cilj ovog rada je da se pozabavi prednostima predavanja stranog jezika u okviru kulturološkog okvira, što podrazumeva podučavanje izučavanih jedinica kroz tekstove knjiga i pesama, scenarije filmova i transkripte kompjuterskih igrica. Ovakvi pisani izvori mogu biti propraćeni i vizuelnim sadržajima, koji su još interesantniji (puštanje pesama $\mathrm{i}$ inserata $\mathrm{i}$ klipova iz filmova i igrica). Budući da je učenicima ovakav materijal u velikoj meri poznat, oni lakše pamte obrađene jedinice. Cilj je i da se testira ovakav pristup i ustanovi da li je učinkovit u savladavanju vokabulara i da li podiže nivo zadovoljstva na času. Zaključci u radu doneti su na osnovu sprovedenog istraživanja. Istraživanje se bavi uzorkom od 30 osnovaca i srednjoškolaca koji su pohađali kurs engleskog jezika u privatnoj školi u Novom Sadu. Jedinice vokabulara predavane su kontrolnoj grupi korišćenjem udžbenika na način koji je predložen u nastavnom planu za nastavnike $\mathrm{i}$ nalazi se u propratnom materijalu za kurs (knjiga za nastavnike). Eksperimentalna grupa koristila je audio- i vizuelni materijal iz pesama, kompjuterskih igrica i filmova odabranih na osnovu svetski poznatih sadržaja. Rezultati testa pokazali su da je nivo zadovoljstva časom kod učenika u eksperimentalnoj grupi bio veći u odnosu na učenike kontrolne grupe, a poboljšalo se i njihovo poznavanje obrađenog vokabulara. 
Ovakvi sadržaji mogli bi da igraju značajnu ulogu u uvođenju jezičkih jedinica (vokabulara) ili u dopunjavanju postojećeg gradiva.

Ključne reči: popularna kultura, pesme, filmovi, kompjuterske igrice, engleski kao strani jezik, zadovoljstvo, savladavanje vokabulara.

Received: 15 May 2019 Accepted: 19 August 2019 